\title{
Influence of the Mills Maintenance on Their Capacity
}

\author{
Lidija Joleska Bureska
}

ELEM, TPP Bitola-Bitola, Macedonia

Copyright $@ 2018$ by authors, all rights reserved. Authors agree that this article remains permanently open access under the terms of the Creative Commons Attribution License 4.0 International License

\begin{abstract}
The good working condition of the mills is very important for boilers, which use coal dust. The mills are very important for Power Plants because their work have a direct influence on the combustion process in the boiler furnace. On time controlling the mills condition and their correct repairing during a revision in accordance, technical standards enable unhindered work of the mills with a maximal load. Depending on the coal quality, a maximal load of the mills directly enables increasing of the heat in the boiler. In continue of the paper are shown the characteristic, parameters and capacity of the fans mills during tests: before overhaul (with current maintenance, with partial reparation with a lot of shortcomings) and after overhaul (with complete reparation). According to the received results, a comparative analyze was made for the effect of the mills' condition on the capacity of the boiler and of course of the Power Plant. In order to reach better characteristics of the mills, at the end of paper are mentioned measures for increasing mills' capacity for $20 \mathrm{t} / \mathrm{h}$ with execution technically properly overhaul, with elimination on all gaps in the mills, with improving sealing on the whole coal line etc.
\end{abstract}

Keywords Mill, Coal, Proper and Periodical Maintenance

\section{Introduction}

The system for preparing coal dust includes milling and drying the coal. In the individual systems for preparing coal dust with a direct inlet of fuel in the boiler, are used mills with different constructions depending on the coal quality. In this case, in Power Plant Bitola, are implemented fan-mills. There, for coal drying, are using a mixture of heated air and hot recycled gas.

The mills, which are the base elements on the system for preparing the coal for fly combustion, enable coal milling and drying and then getting coal dust with certain granulation and humidity of the particles.

With every significant change of their maintenance and coal quality, is necessary to perform the analysis of potential impact of those changes on the combustion process in the furnace. As a consequence of the mills' maintenance and changeable quality of coal, for the combustion process, the most significant ones are: quality of coal dust, disposition of coal dust by burners' levels, temperatures and velocity of the air-mixture at the burner output. The impact of the combustion process on slagging the furnace and soiling convective surfaces appears to be especially important [16].

In TPP Bitola every boiler has per 6 mills. Their disposition is three from the left and three from the right side of the furnace. Distribution the air-mixture in the furnace height is with 12 main jet burners, vertically disposed, in two levels. Above of them are installed 6 vapor burners so-called reactive burners (fig. 1). The boilers in TPP Bitola are Ramzeen type, T-form, designed as Pp-670-140GOST3619-76, but known as P-65 (fig.1). The boilers are designed to operate with lignite coal with lower calorific value (LCV) in a range $6180-8100 \mathrm{KJ} / \mathrm{kg}$, characterized with moisture content up to $50 \%$ and with ash content between 12 and $20 \%$.

The main characteristics of the boiler are:

- $\quad$ maximum production of primary steam $700 \mathrm{t} / \mathrm{h}$,

- temperature of primary steam $545^{\circ} \mathrm{C}$,

- pressure of primary steam $13,8 \mathrm{MPa}$,

- temperature of secondary steam $545^{\circ} \mathrm{C}$,

- pressure of secondary steam $3,2 \mathrm{MPa}$,

- $\quad$ temperature of feed water $252^{\circ} \mathrm{C}$. 


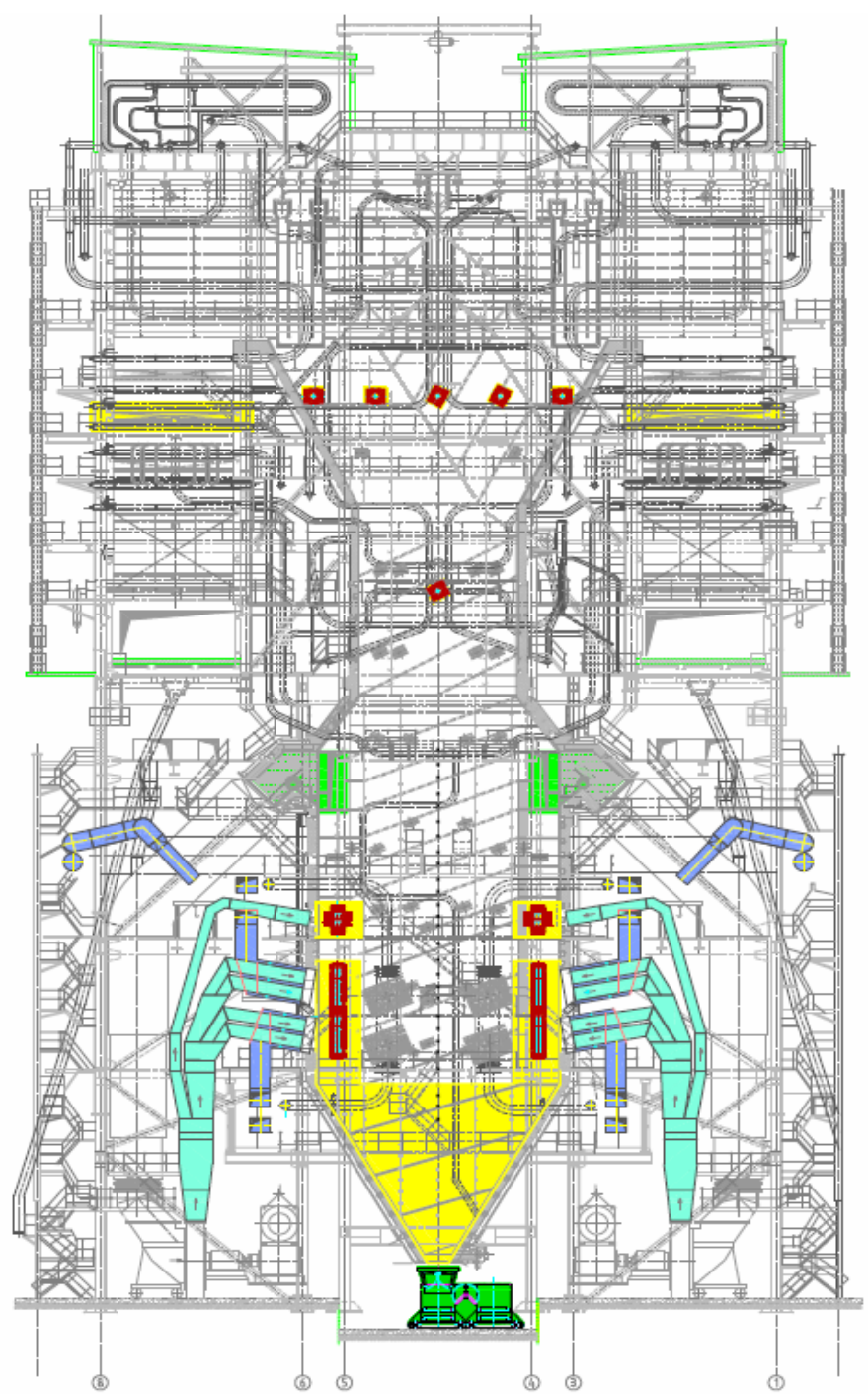

Figure. 1. A schematic representation of the boilers installed in TPP Bitola [1]

The furnace of the boiler has an octagonal form and in the upper part is made narrower and is transforming to the quadrangle cross-section. The walls on the furnace are with the screen tubes so called lower, middle and upper radiation part. At the end of the furnace (in the horizontal gas pass) are installed superheaters. In the convective pass are installed convective superheaters for primary and secondary steam, transition part and water heater (economizer). The air for combustion is provided with two fans. With a regenerative heater the air is heated to temperature $302^{\circ} \mathrm{C}$. With the two fans for gas, is providing under pressure in the furnace 30 to $50 \mathrm{~Pa}$.

\section{Mills Description}

The mills installed in TPP Bitola, which are subject for analyze are fan-mills, type KSGN.220.50, with a diameter on the wheel $3400 \mathrm{~mm}$ and capacity $63 \mathrm{t} / \mathrm{h}$. Design of the mills is shown on the fig.2. Through the inlet open (1), coal and hot recirculation gas are brought axially in the mills' rotor installed in the spiral case (5). Milling of the coal is made by hitting massive blow plates (3), passing across the wheel (2) and by sliding. During milling, gas for drying makes a cool rapidly, that is a result the intensive drying of the coal dust. Air mixture (the mixture of coal dust with drying products) passes through the classifier (6) there the biggest pieces are selected and returned to the mill for re-milling through the duct (7). The small pieces i.e. coal dust and drying products go to the burners. In the mill, the mineral abrasive materials (which have bigger density than the coal), and particles of steel.

(That are products of abrasion the mills' elements) are circulating with the cold products of drying. Those materials have an abrasive effect on the mills' elements, are reducing their lifetime and cause a reduction on ventilation the mill [2][4]. 

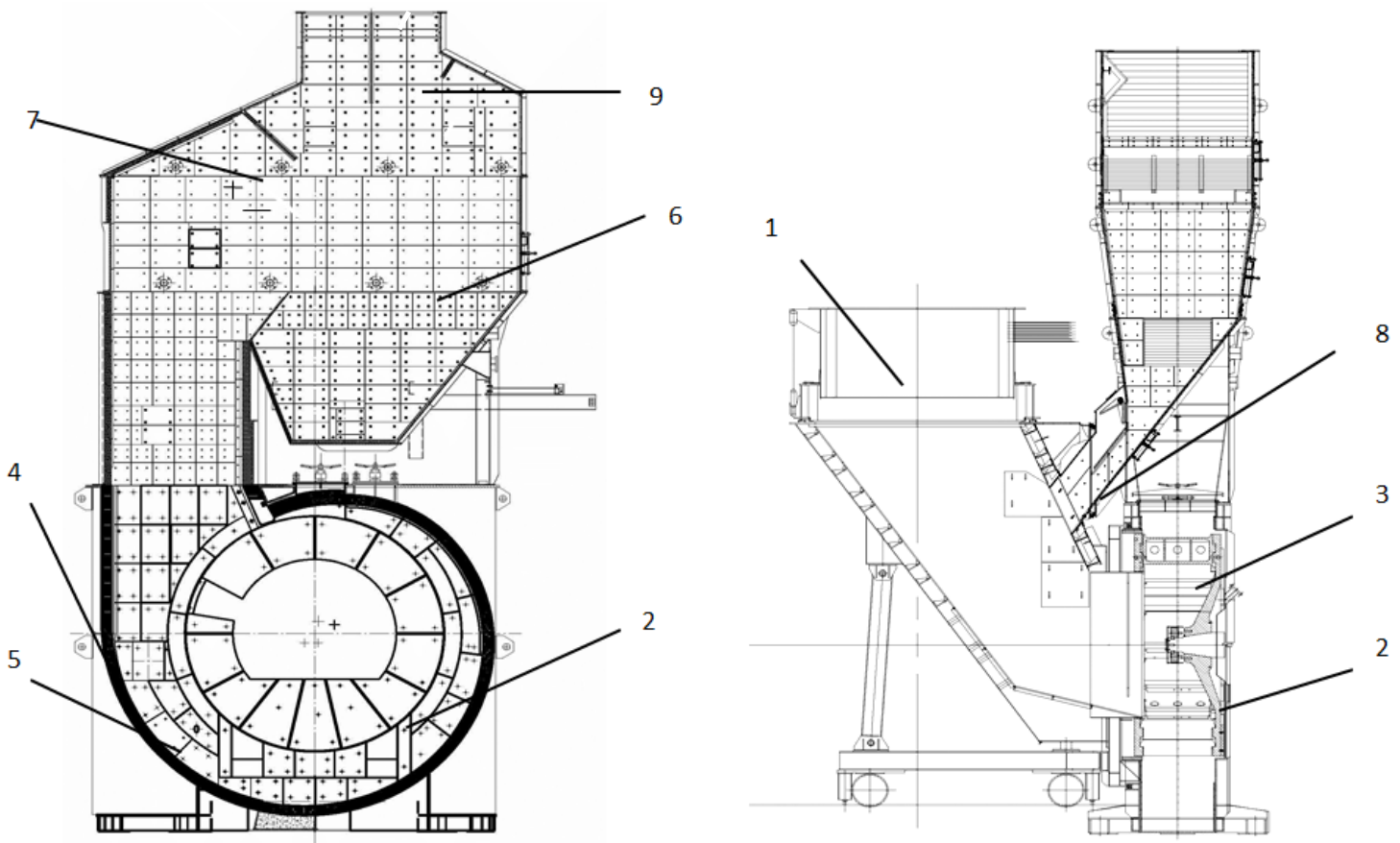

1.Entrance for coal and fluid for drying; 2.Mills' wheel; 3.Impact plates; 4.Mills' casing; 5. Spiral in the casing; 6.Classifier; 7. Regulation flap; 8.Returned duct; 9.Air mixture outlet. [3]

Figure.2. Design of the fan mill, typeKSGN.220.50

Because of that, mills have to be on time reviewed and repaired with a replacement the wear parts. If reviewing or repairing is not made on time or is made only with partial repairing, then abrasion is continuing, the main dimension of the mills' parts are changing and are increasing the gaps between rotor and stator. Those increased gaps disable properly work of the mills, which is demonstrated with reducing the capacity and changing the working parameters of the mill.

\section{Results of the Mills' Tests}

The last years, received coal from the mines was with worse quality, in comparison with projected quality. Because we had needs for the electricity production, was very important the mills to work with maximal load with bad coal quality (i.e. coal on the bottom limit of the project range and under it). For determining the capacity of the mills with bad coal quality, was made several tests, before and after complete repairing of the mills. The parameters of the mills were recorded in the digital system for control the unit, so-called DCS (Digital Control System). During the tests were taken coals samples from every feeder, and their analyses were done in our chemical laboratory.

\subsection{Test on the Mills before Overhaul}

In this test, the mills were tested one per one, with a load of $185 \mathrm{MW}$ on the Power Plant. During the test whole equipment from the current coal line, were put on a manual command, starting from the coal feeder, flap for the primary air, flap for returned gas and mill. After that, the load of a mill was increased, as long as the parameters were stable. The coal feeder was loading until the temperature of the air-mixture behind classifier was reached $130^{\circ} \mathrm{C}$. After the short phase of process stabilization, the temperature was reduced and limited to $120^{\circ} \mathrm{C}$.

Measurements of the mills were performed with stable parameters and conditions. During the test were done the follows measurements: the temperature in the spiral of the mills' casing, a flow of the coal dust through every section of duct for air-mixture, with the extraction of samples, coal flow in the mill so-called dosimetry (with those measurements were checked calculated coal quantity from DCS-Digital Control System). Other parameters, a temperature of the air mixture behind classifier and temperature of gas recirculated were taken from continually process measurements i.e. DSC. Parts from the measured values during the mills' measurement separate are shown in table 1.

\subsection{Test of Boiler Steam Production-Test 1}

After completion the separate tests of the mills, they were returned on an automatic mod and was continued the test of boiler maximal steam production. The initial steam flow was $564 \mathrm{t} / \mathrm{h}$ or $192 \mathrm{MWe}$. Increasing of the load was very slow because it had an fluctuation of under pressure in the furnace. The maximum steam production achieved during the test was $606 \mathrm{t} / \mathrm{h}$, or 204MWe. The test was planned with 5 mills in operation, but due to the problem with the under pressure in the furnace, the test was made with 6 mills. The parameters on the mills during the maximum load of the boiler are shown in table 2 . 
Table 1. Data saved, during the separate tests on the mills [5]

\begin{tabular}{|l|c|c|c|c|c|c|c|}
\hline \multicolumn{1}{|c|}{ Mill No. } & & 1 & 2 & 3 & 4 & 5 & 6 \\
\hline A temperature in a duct for recirculation & ${ }^{0} \mathrm{C}$ & 928 & 854 & 668 & 913 & 774 & 868 \\
\hline Temperature air-mixture behind classifier & ${ }^{0} \mathrm{C}$ & 117 & 129 & 121 & 121 & 126 & 117 \\
\hline The flow of the primary air & $\mathrm{Nm}^{3} / \mathrm{h}$ & 0 & 0 & 0 & 0 & 0 & 0 \\
\hline The position on the flap for returned gas & - & Close & $\mathrm{Close}$ & Close & Close & Close & Close \\
\hline Working hours of the mill's wheels & $\mathrm{h}$ & 1500 & 0 & 204 & 1239 & 1468 & 1031 \\
\hline Coal flow acc. DCS calculation & $\mathrm{t} / \mathrm{h}$ & 57,60 & 66,90 & 60,18 & 57,14 & 50,22 & 54,70 \\
\hline Coal flow acc. measurement-dosimetry & $\mathrm{t} / \mathrm{h}$ & 57,24 & 63,13 & 58,38 & 56,55 & 51,41 & 54,29 \\
\hline Low Heat Value of coal -LHV & $\mathrm{KJ} / \mathrm{kg}$ & 6001 & 6222 & 5449 & 5283 & 6554 & 6642 \\
\hline The water content in coal, W & $\%$ & 47,74 & 47,83 & 48,47 & 46,10 & 47,67 & 48,40 \\
\hline The ash content in coal -A & $\%$ & 20,49 & 20,90 & 22,08 & 25,97 & 20,36 & 21,12 \\
\hline
\end{tabular}

Table 2. Data of the mills, during test 1 , and with the boiler steam production $606 \mathrm{t} / \mathrm{h}$ ( 204MWe)[5]

\begin{tabular}{|l|c|c|c|c|c|c|c|}
\hline \multicolumn{1}{|c|}{ Mill No. } & & 1 & 2 & 3 & 4 & 5 & 6 \\
\hline Coal flow acc. DCS calculation & $\mathrm{t} / \mathrm{h}$ & 54,50 & 61,70 & 55,5 & 53,3 & 54,4 & 49,3 \\
\hline Temperature air-mixture behind classifier & ${ }^{0} \mathrm{C}$ & 137 & 131 & 133 & 135 & 130 & 134 \\
\hline A temperature in the duct for recirculation & ${ }^{0} \mathrm{C}$ & 912 & 906 & 854 & 917 & 750 & 896 \\
\hline Low Heat Value of coal -LHV & $\mathrm{KJ} / \mathrm{kg}$ & \multicolumn{5}{|c|}{5911} \\
\hline Summarized coal flow in all mills & $\mathrm{t} / \mathrm{h}$ & \multicolumn{5}{|c|}{328,8} \\
\hline
\end{tabular}

\subsection{Test on the Mills after an Overhaul}

After the mills' overhaul, again was organized testing. During the mills' overhaul, have been taken following activities: removing the welded parts from unallowed places inside in the mills (that increasing the resistance in mills, fig.3, 4 and 5), replacement of the wear parts in the stator and in the mills' door, replacement and repairing the plates in the classifier, replacement the wear part on the flaps in distributor, repairing of the mills' casing and etc.

In order to reduce the gap between mills' rotor and stator (fig.6) were installed new wheels and new rings. Also, during the mills' overhaul, was repaired sealing of the whole coal line, starting with the coal feeders, coal conveyors and to the mills (fig.7). The procedure for test on the mills was the same with the previous test. During the test, Power Plant had a power between 190 to $200 \mathrm{MWe}$, or 600 to $680 \mathrm{t} / \mathrm{h}$ steam production. Parts of the saved data are shown in table 3 .

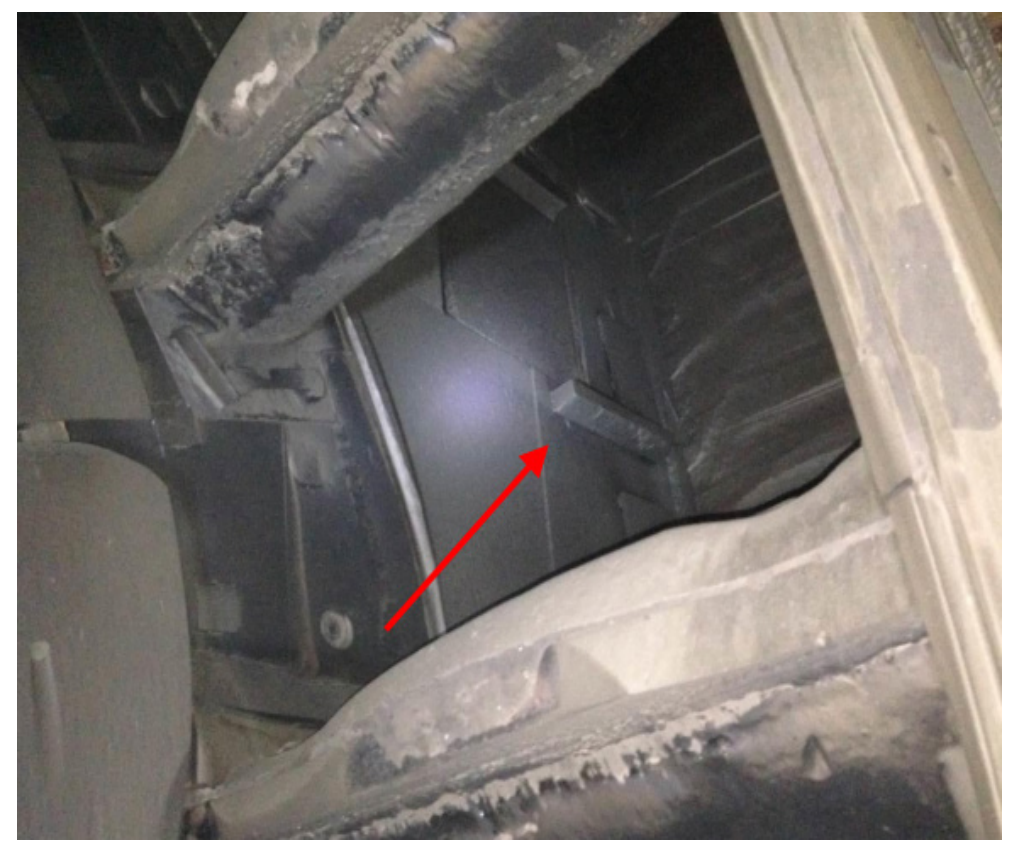

Figure 3. Removed parts from the upper side on mills' spiral[5] 


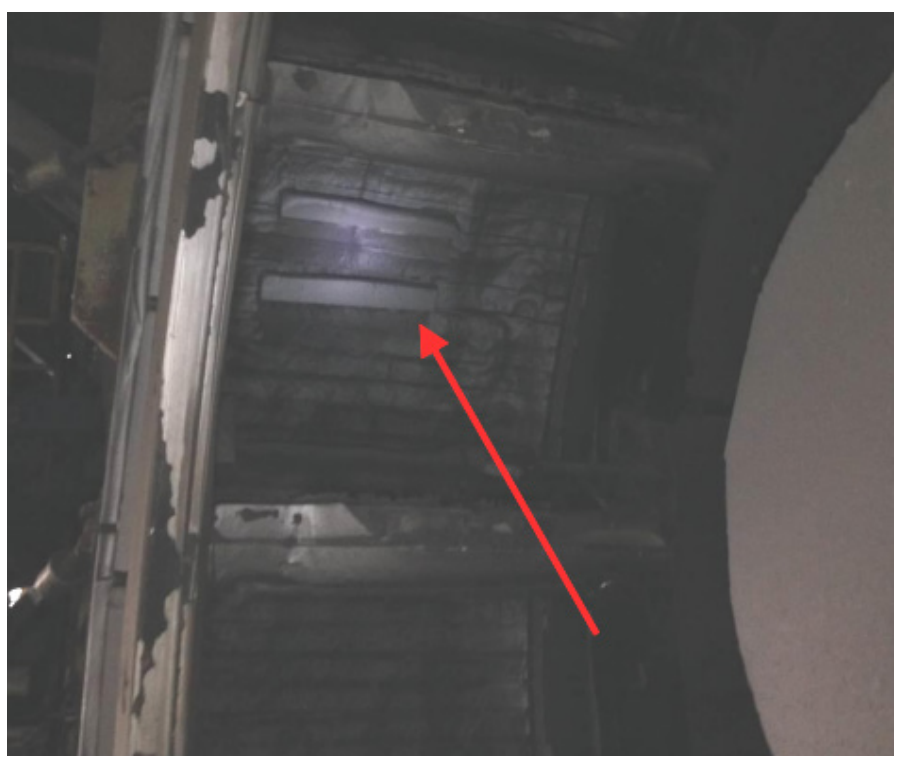

Figure 4. Removed parts from the upper part in the mill [5]

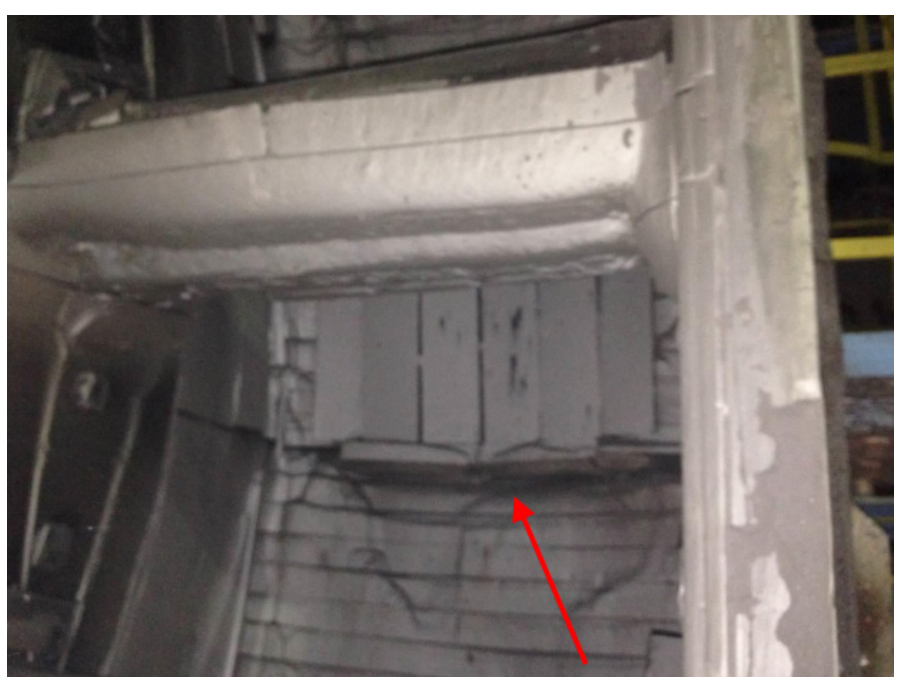

Figure 5. Removed parts from theleft and right sideon the mills'spiral [5]

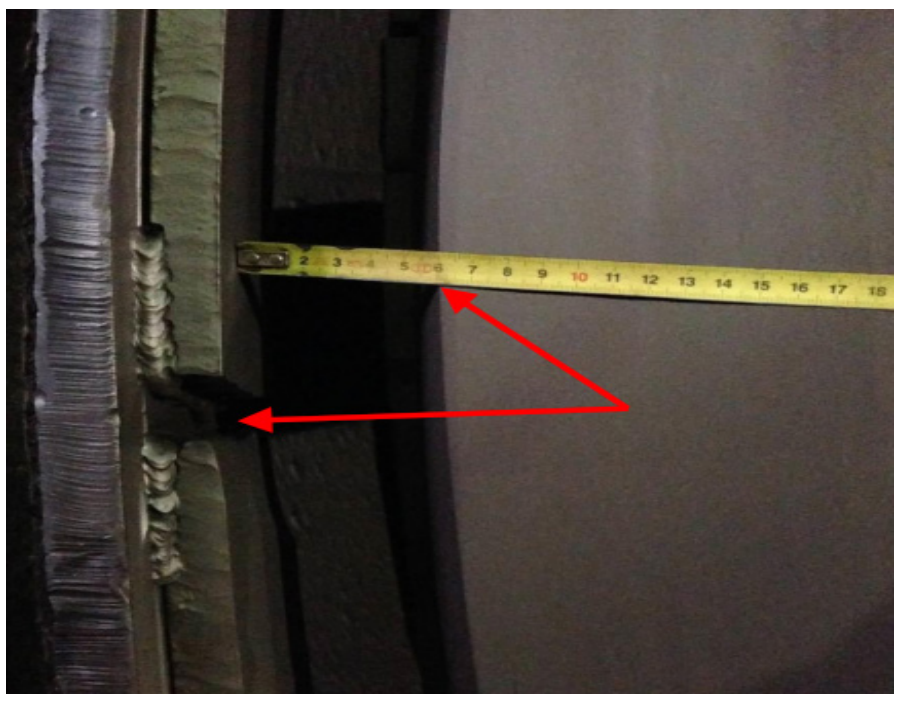

Figure 6. The gap between mills' rotor and stator [5] 


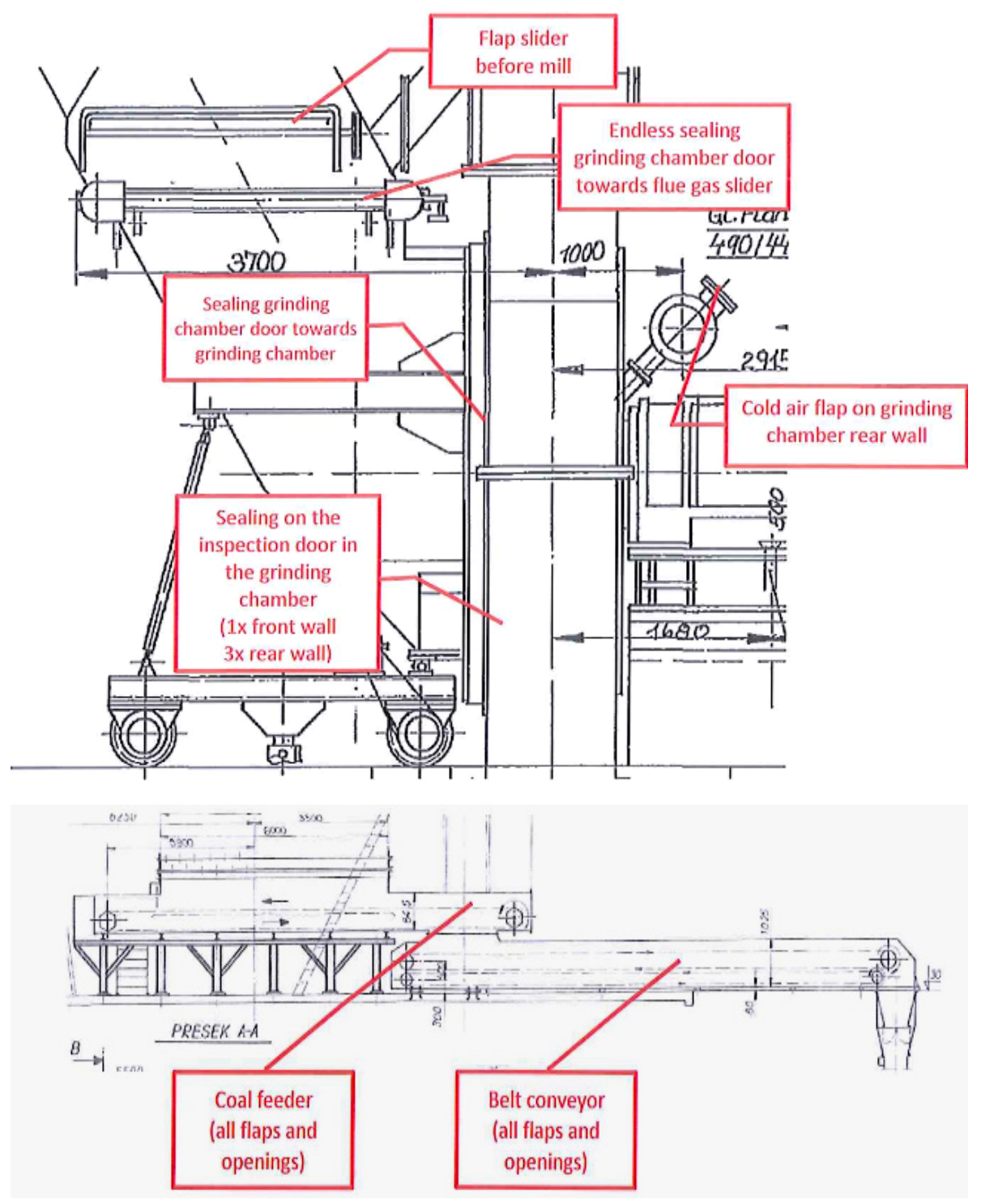

Figure 7. The places where have been repaired sealing on the mills, coal feeders and conveyer [6].

Table 3. Data saved, during separate tests of the mills after their overhaul [6]

\begin{tabular}{|l|c|c|c|c|c|c|c|}
\hline \multicolumn{1}{|c|}{ Mill No. } & & 1 & 2 & 3 & 4 & 5 & 6 \\
\hline Coal flow acc. DCS calculation & $\mathrm{t} / \mathrm{h}$ & 66,0 & 60,5 & 64,5 & 70,0 & 70,5 & 65,0 \\
\hline $\begin{array}{l}\text { Temperature the air-mixture behind } \\
\text { classifier }\end{array}$ & ${ }^{0} \mathrm{C}$ & 141 & 133 & 128 & 134 & 149 & 130 \\
\hline Working hours of the mill's wheel & $\mathrm{h}$ & 395 & 402 & 398 & 403 & 409 & 402 \\
\hline Low Heat Value of coal -LHV & $\mathrm{KJ} / \mathrm{kg}$ & 6690 & 6430 & 6430 & 6430 & 6100 & 5870 \\
\hline
\end{tabular}

\subsection{Test of Boiler Capacity (Steam Production) after the Mills' Overhaul, Test 2 and 3}

After the mills' overhaul were organized two tests of boilers capacity. The initial power the Power Plant on the first test (in continuation marked with Test 2) was $190 \mathrm{MWe}$ or $606 \mathrm{t} / \mathrm{h}$, steam production and 5 mills in operation. Maximum achieved power during Test 2, was $214 \mathrm{MWe}$, or $660 \mathrm{t} / \mathrm{h}$ steam production. During the second test (in continuation marked with Test 3) was achieved maximum power $217 \mathrm{MWe}$, and steam production $670 \mathrm{t} / \mathrm{h}$. The parameters of the mills and coal quality during both tests are shown in table 4.

Changes the main parameters of the boiler, during Test 2, saved in DCS, are shown in fig.8. On fig.9, are shown changes the air mixture temperature behind classifier, during Test 2 . 
Table 4. Data saved during test 2 and 3[6].

\begin{tabular}{|c|c|c|c|c|c|c|c|c|c|c|}
\hline & Mill No. & MV1 & MV3 & MV4 & MV5 & MV6 & $\begin{array}{l}\text { Total coal } \\
\text { flow }\end{array}$ & $\begin{array}{r}\text { Low } \mathrm{H} \\
\text { of co } \\
{[\mathrm{k}} \\
\end{array}$ & $\begin{array}{l}\text { Value } \\
\text { LHV } \\
\text { g] }\end{array}$ & $\begin{array}{c}\text { Steam } \\
\text { production } \\
{[\mathrm{t} / \mathrm{h}]}\end{array}$ \\
\hline \multirow{3}{*}{ Test 2} & $\begin{array}{l}\text { Coal flow acc. DCS } \\
\text { calculation }[\mathrm{t} / \mathrm{h}]\end{array}$ & 62 & 63 & 58 & 68 & 53 & \multirow{3}{*}{304} & \multicolumn{2}{|c|}{6640} & \multirow{3}{*}{660} \\
\hline & \multirow{2}{*}{$\begin{array}{l}\text { Temperature air-mixture } \\
\text { behind class. }\left[{ }^{0} \mathrm{C}\right]\end{array}$} & \multirow{2}{*}{167} & \multirow{2}{*}{163} & \multirow{2}{*}{166} & \multirow{2}{*}{166} & \multirow{2}{*}{165} & & A \% & W \% & \\
\hline & & & & & & & & 16,6 & 51,8 & \\
\hline \multirow{3}{*}{ Test 3} & $\begin{array}{l}\text { Coal flow acc. DCS } \\
\text { calculation }[\mathrm{t} / \mathrm{h}]\end{array}$ & 69 & 58 & 64 & 69 & 62 & \multirow{3}{*}{322} & \multicolumn{2}{|c|}{6140} & \multirow{3}{*}{670} \\
\hline & \multirow{2}{*}{$\begin{array}{l}\text { Temperature the air-mixture } \\
\text { behind class. }\left[{ }^{\circ} \mathrm{C}\right]\end{array}$} & \multirow{2}{*}{152} & \multirow{2}{*}{130} & \multirow{2}{*}{144} & \multirow{2}{*}{144} & \multirow{2}{*}{138} & & A \% & W \% & \\
\hline & & & & & & & & 21 & 51 & \\
\hline
\end{tabular}

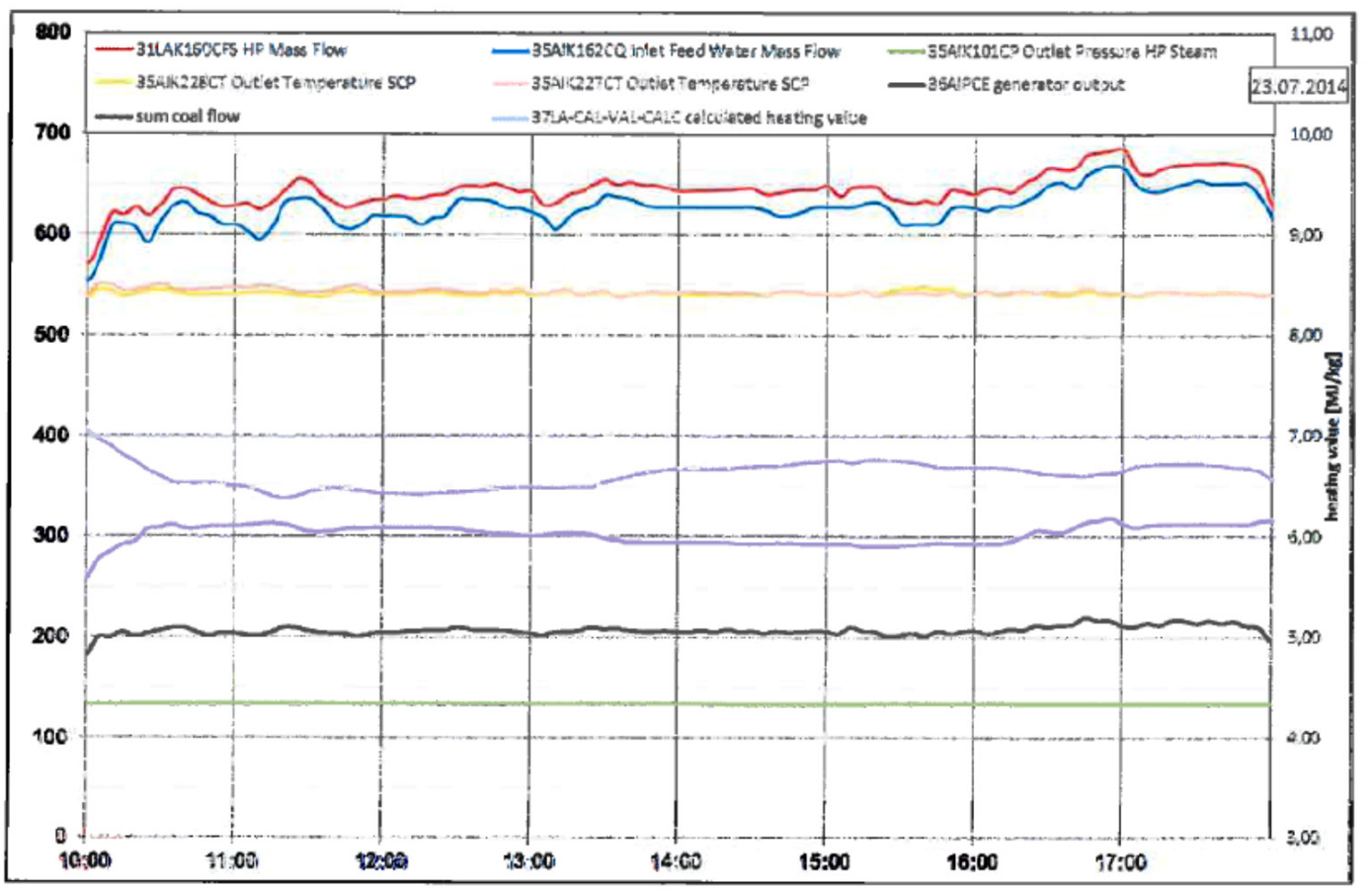

Figure 8. The main data during Test 2, saved in DCS, [6].

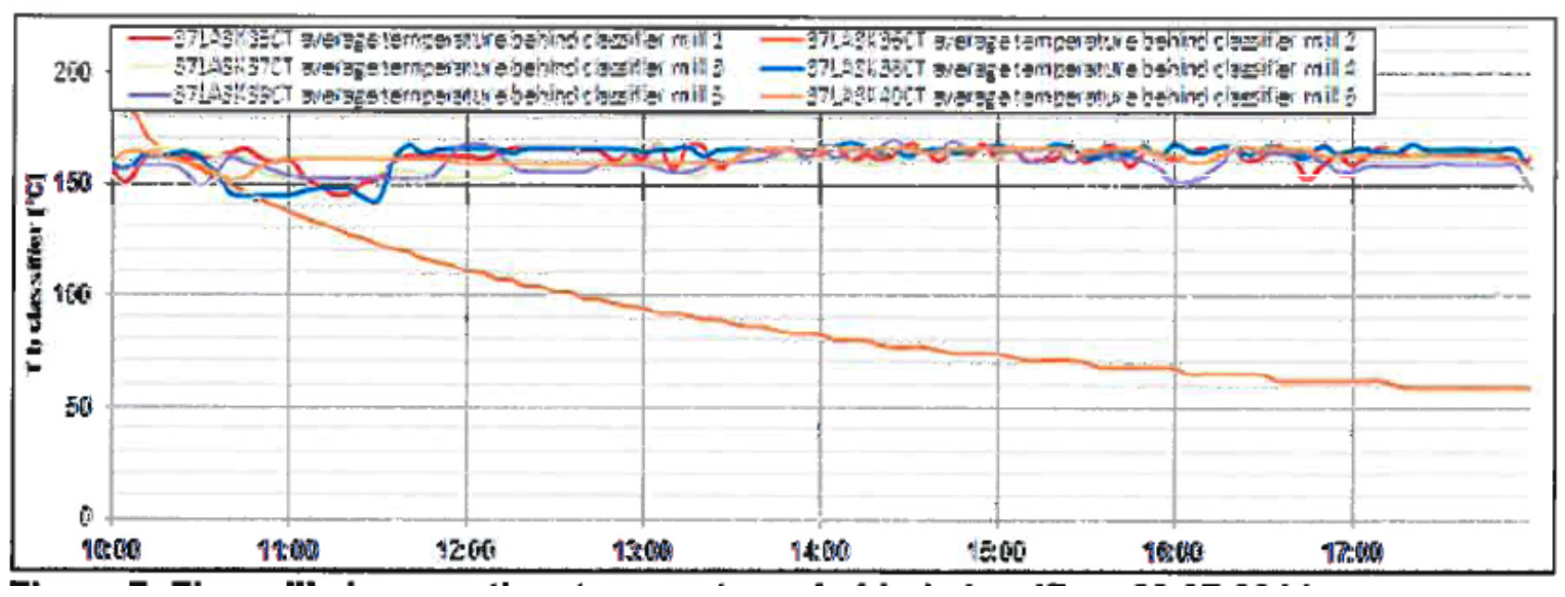

Figure 9. Temperature the air mixture behind classifier during Test 2, saved in DCS [6]. 
The maximum achieved steam production during Test 2 was $660 \mathrm{t} / \mathrm{h}$. A higher load of the boiler has not been possible because the ID fans were worked on the maximum operation point (that problem is out of this research). From the diagram on fig. 9 can be seen that temperature the air mixture behind classifier, is above $150^{\circ} \mathrm{C}$ all time during
Test 2. This means the mills were able for a higher load. In order to check and confirm the results from Test 2 that the next day was organized a second test, so-called Test 3. Procedure for Test 3 was the same as Test 2, and conditions were similar. The main data during Test 3 saved in DCS, are shown on fig. 10 and 11.

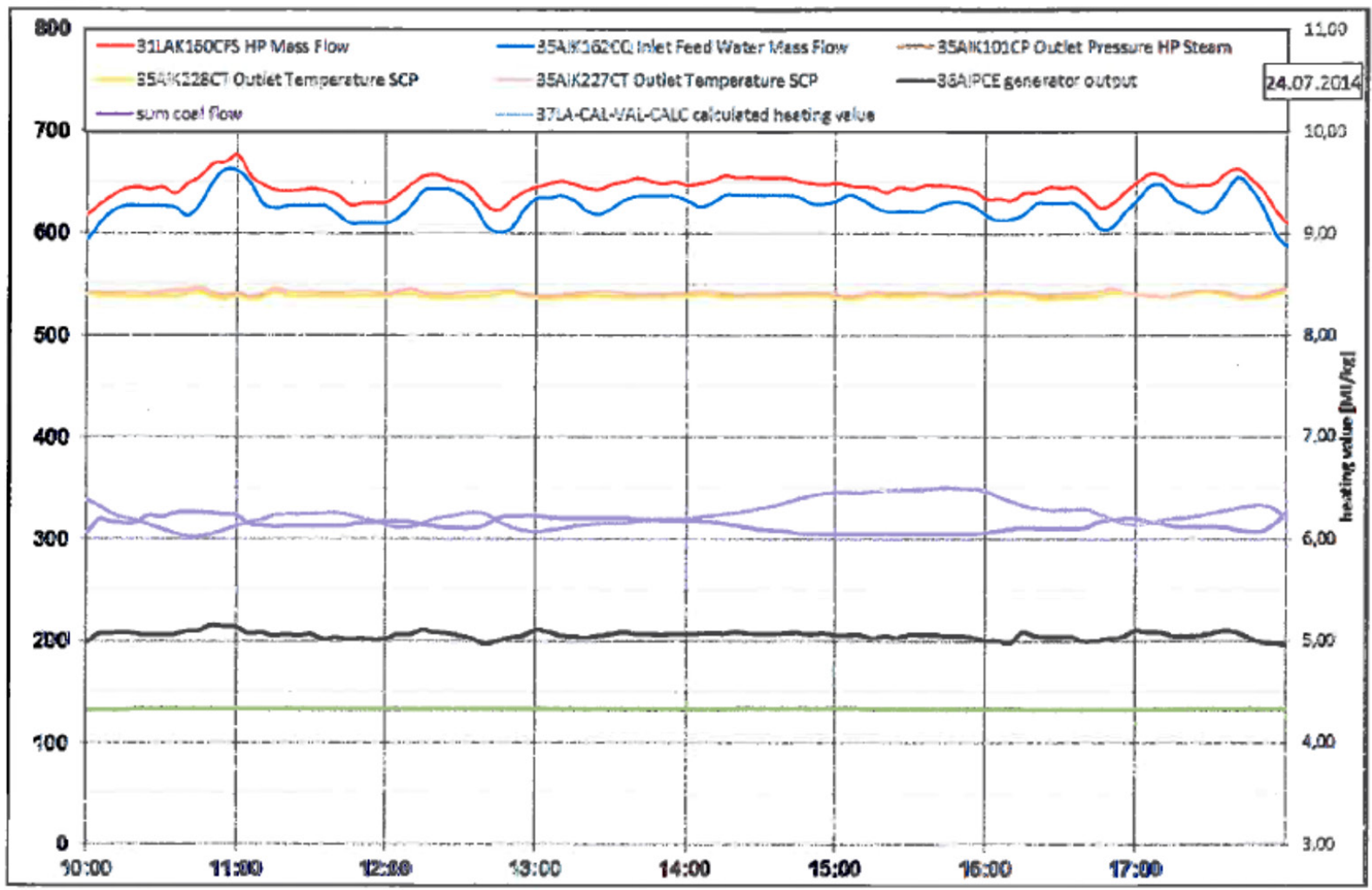

Figure 10. The main data during Test 3, saved in DCS, [6].

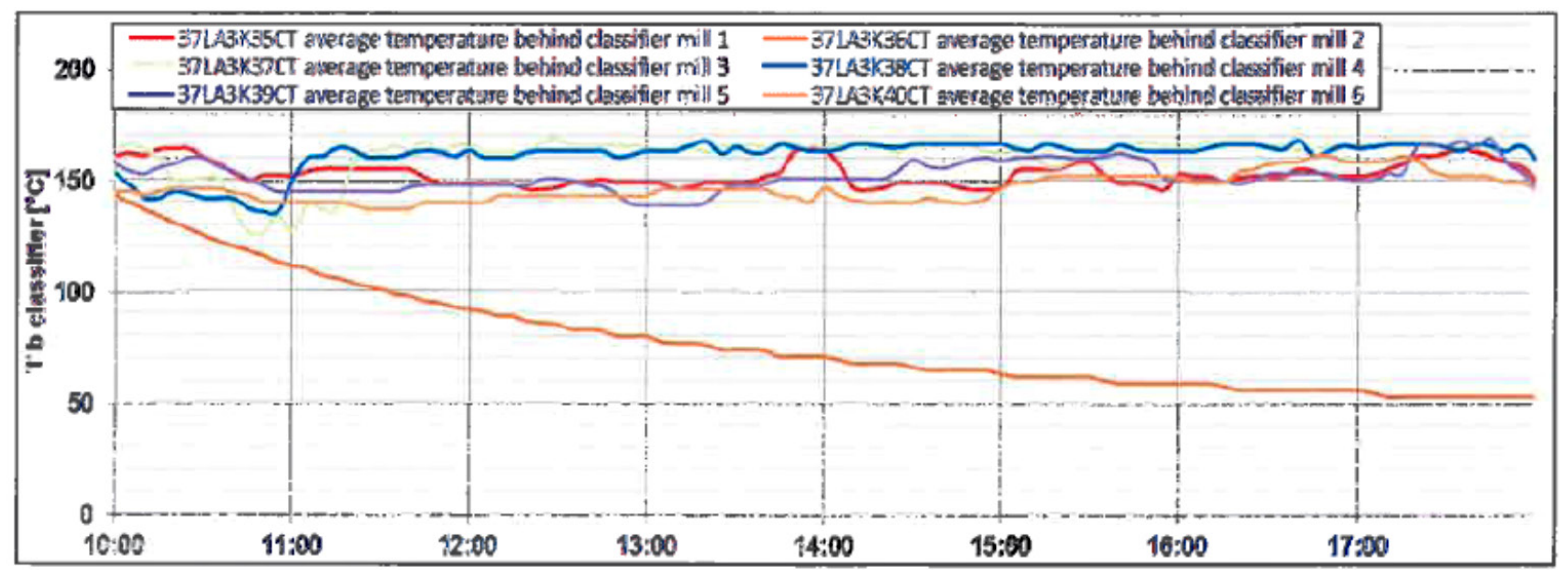

Figure 11. The air mixture behind classifier during Test 3, saved in DCS [6] 


\section{Comparison and Analyze of the Results of Tests}

The analyzed consists two parts. In the first part are analyzed results from the mills' tests, and in the second are analyzed results from the boiler steam production tests i.e. data of mills during those tests.

\subsection{The Analyze of Results from the Mills' Tests}

In the base of results from the tests, is made a diagram, fig.12. In diagram are shown trends of coal quantity per mill, temperature of air mixture behind classifier and coal quality, during testing every mill.

With the comparison of the results from tests of the mills before and after overhaul can be concluded that:
- Test before the overhaul was made with worse coal quality than after overhaul test. The first test on the mills MV1, 3 and 4 was made with worse coal quality. On mill MV2 during both tests coal quality was almost the same, and on mills MV 5 and 6 with better coal quality, during the first testing.

- The capacity of the mills during the first test (before their overhaul) was lower than in the second test (after overhaul). During the second test, the capacity of the mills was increased, and somewhere to $20 \mathrm{t} / \mathrm{h}$, except mill MV2, where coal quantity was reduced for almost $6 \mathrm{t} / \mathrm{h}$. Changes of the mills' capacity after the overhaul are shown on the diagram fig. 13.

- The temperature of the air mixture behind classifier, after the mills' overhaul is higher than before overhaul. That is a result of successful repairing the sealing on the coal lines. Because of that, mills were able for a higher load.

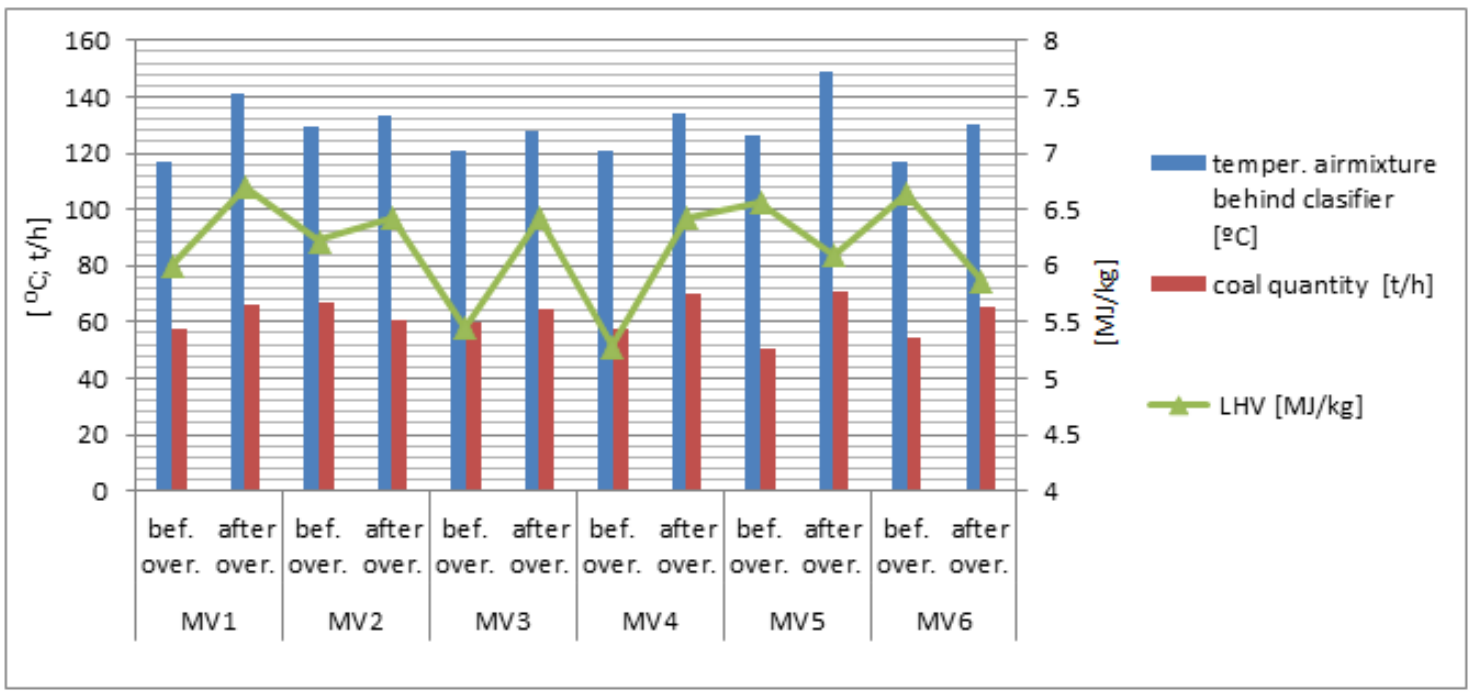

Figure.12. Changes of the temperature the air mixtures behind classifier and coal flow in mills, before and after overhaul.

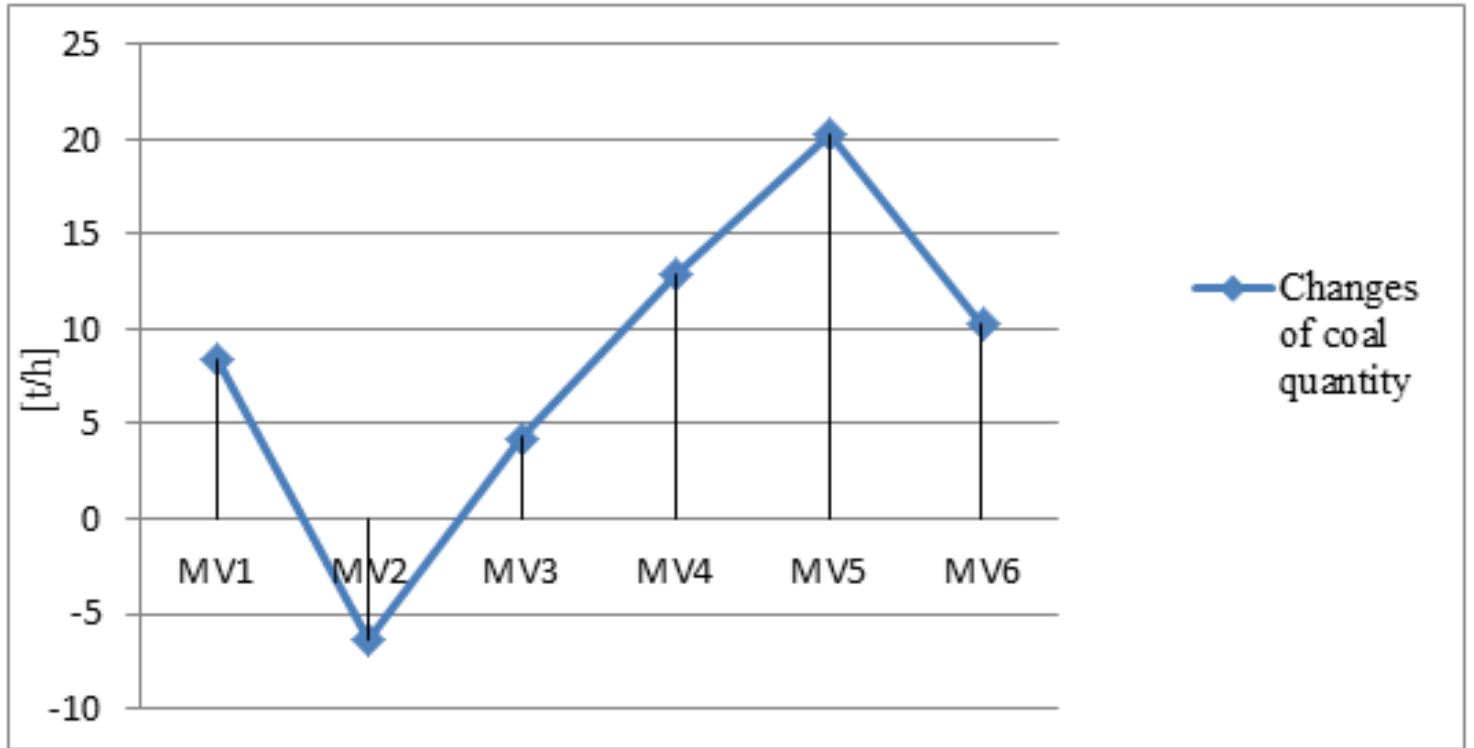

Figure 13. Changes of the capacity the mills after the overhaul, compared to the capacity before overhaul. 


\subsection{The Analyze of the Results from a Test of Boiler Steam Production, i.e. Data of Mills during Those Tests}

On the diagram in fig.14. are shown the results from the three tests. The first test (test 1) was made before the overhaul of the mills, and two other (test 2 and 3) were made after that. Test 1 was performed with 6 mills in operation, while tests 2 and 3 with 5 mills in operation. Data of the mills, during the tests, are shown in the diagram on fig. 15 .

From the results of tests shown in the diagram, fig. 15 can be concluded following:

- Test 2 was performed with better coal quality than test 1 and 3 . Because of that, for the next comparison and analyze will be used only data from test 1 and 3 .

- Tests 1 and 3 were performed with insignificant differences between coal quantity and quality. Test 1 , was performed with 6 mills in operation and test 3 with 5 mills. The results are showing that after the overhaul of the mills, their capacity was increased, and in some of the mills, capacity was increased by $20 \mathrm{t} / \mathrm{h}$. Those changes can be seen in the diagrams, fig. 13 and 15 .

- In test 3, steam production in the boiler was higher (by $70 \mathrm{t} / \mathrm{h}$ ), than in test 1 . That means, during test 3 , in the boiler was better used coal in the furnace i.e. in this test had better combustion, which is the result of better coal dust preparing, among other things.

During test 3 , the temperature of the air mixture behind classifier was in the range from $130^{\circ} \mathrm{C}$ (on MV2) to $152^{\circ} \mathrm{C}$ (on MV1). The mills with a higher temperature than $130^{\circ} \mathrm{C}$, have a possibility to work with an increased load. And the increased load of the mills enables increasing of the boiler steam production.

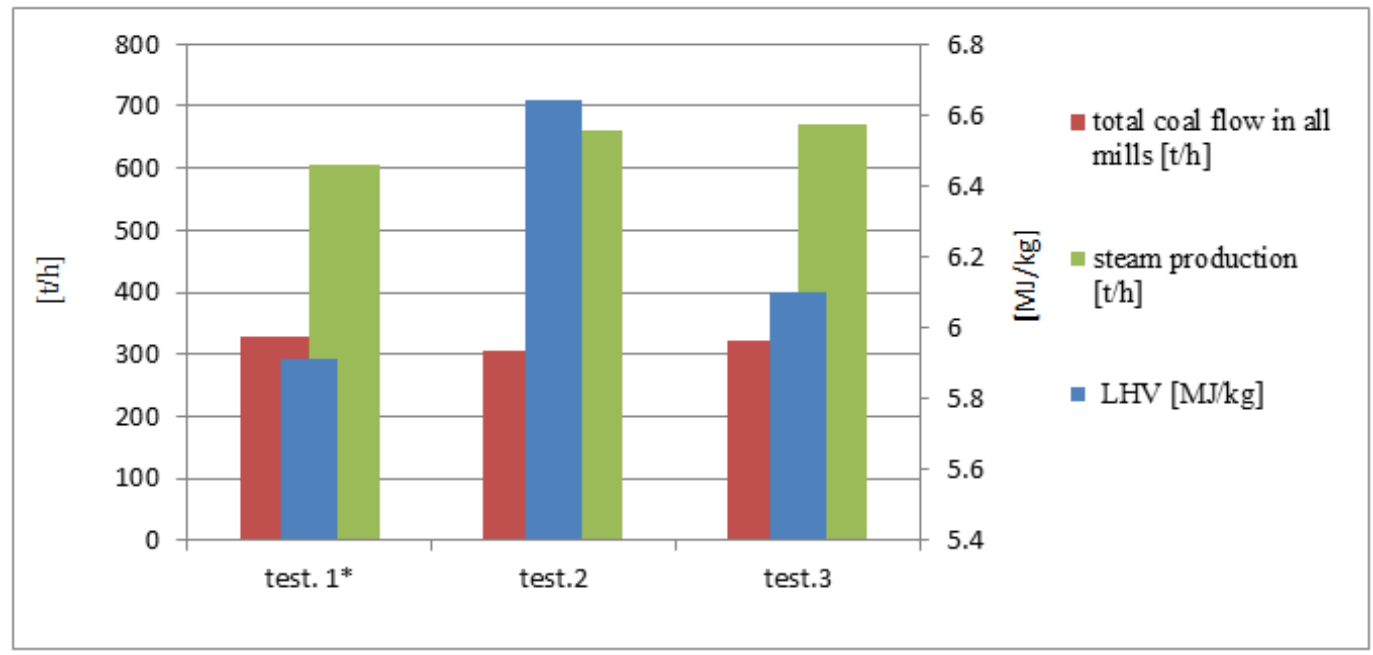

Figure 14. Diagram with boiler steam production during the three tests: test $1 *$-before mills' overhaul, test 2 and 3 - after mills' overhaul; * test is made with 6 mills in operation.

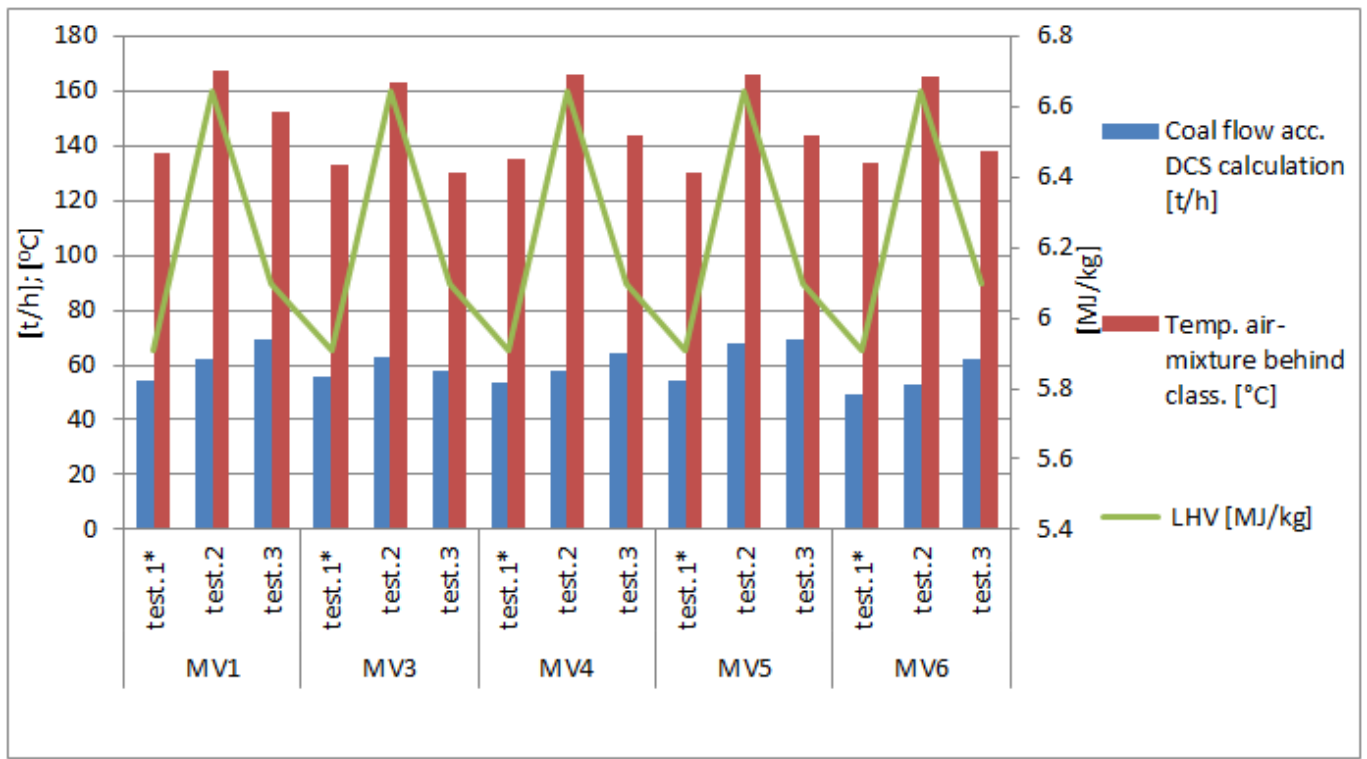

Figure 15. Diagram with mills' data during the three tests: test $1 *$-before mills overhaul, test 2 and 3 - after mills overhaul; * test was made with 6 mills in operation. 


\section{Conclusions}

From the above-analyzed results of the mills and boiler tests, can be concluded that for reaching the maximum load of the mills is necessary:

- $\quad$ Performing the technically properly overhaul on the mills. That means repairing the spiral part of the stator without any obstacles (welded parts in unallowed place inside in the mill, fig.3, 4 and 5). The existence of that obstacle on the mills' stator is increasing resistance inside in the mills casing and reduce their ventilation power.

- Elimination of unallowed gaps in the mills. Here are gaps between installed stators elements and gaps between wheel and stators' elements (fig.6). Those can be eliminated with installing a wheels with project dimensions i.e. installation the properly repaired wheels.

- $\quad$ Providing the sealing of the whole line for coal dust preparing, beginning from the coal feeders, conveyors, ducts for hot gas recirculation and the mills (fig.7).

- Repairing the sealing on the mills in the area of the slide flaps, control doors, flaps for cold air etc.

- Performing the revisions of the mills technically properly, on time and in accordance with a before prepared plan. In a case when mills worked with bad coal quality and higher ash content, a time between revisions have to be reduced. This is necessary for monitoring of abrasion in the mills, which enables their safe work.

\section{REFERENCES}

[1] Babcock Borsing Steinmuller:Technical specification of the Modernization of Unit 1,2,3, Skopje, 2011g.

[2] Petrovski J.Ilija.: Steam boilers, Skopje 2004,

[3] Babcock Borsing Steinmuller: Operation manual, TPP Bitola, Unit 3, 2013

[4] Zivanovic T.; Brkic Lj; Tucakovic D. : Calculation of the plants for preparing coal dust, Mechanical faculty, University in Beograd- Beograd 2005.

[5] Babcock Borsing Steinmuller: Mill Measurements and Load Tests on optimized mills N220.50 of Boiler 3, TPP Bitola, June 2014

[6] Babcock Borsing Steinmuller:Full Load Test at Bitola Power Plant Unit 3, 5 Mills in operation, TPP Bitola, August 2014.

[7] Schubert J, Schouer T.: Mill Test Report-Bitola Power Plant, Unit 3, 11 May 2011

[8] Joleska.B.L.; Filkoski V.R.; Petrovski J.I.: Advanced numerical methods for investigation of energy conversion processes, Power Plants, Vrnjacka Banja, 2010g.
[9] Joleska.B.L.; Filkoski V.R.; Petrovski J.I.: Proposed measures in TPP Bitola for reduction of the nitrogen oxides emission, ZEMAK, 2010g.

[10] Babcock Borsing Steinmuller:, Process Engineering Description of the Control Unit 3,TPP Bitola, 2013,

[11] Pecakov S.:Local instruction for exploitation steam boiler Pp-700-13,8-545 (P65),

[12] Recom Services GmbH, Berreth A., Risio B.: Baseline Simulation Results, Bitola, Unit 3, Stuttgard, 2011.

[13] Babcock Borsing Steinmuller: Operation manual, TPP Bitola, Unit 3, 2013.

[14] Tehnolab doo Skopje: Laboratory reports from 2011 to 2016.

[15] Mining Institute d.o.o. Beograd: Test report, physical and chemical characteristics for coal TPP Bitola - annual analyses from 2011 to 2015 .

[16] Samardzic M.M.; Skundric B.J.:Optimization of pulverizing facility of steam boiler P-64 of 300MW block odTPP Ugljevik, International Conference "Power plants 2016"Zlatibor, Srbija-2016

[17] Brkic Lj.; Hrnjacek M.; Calic M.: Steam boiler special chapters, Mechanical faculty, University in BeogradBeograd 1973. 